\title{
THE URINARY/FECAL COPROPORPHYRIN RATIO IN LIVER DISEASE
}

\author{
By S. ARTHUR LOCALIO, M. STEPHEN SCHWARTZ, AND \\ CATHERINE F. GANNON
}

\begin{abstract}
(From the Departments of Surgery and Medicine, New York Post-Graduate Medical School and Hospital, Columbia University, New York)
\end{abstract}

(Received for publication July 11, 1940)

In addition to the bile pigments, there are present in the urine and stool another series of pyrrole pigments, the porphyrins. Hemoglobin, myoglobin, and other respiratory pigments contain as their prosthetic group a porphyrin of Type III configuration. The porphyrin excreted in urine and feces by normal individuals, and in most pathological states, is coproporphyrin Type I. This substance cannot be derived by degradation of the Type III porphyrins present in the respiratory pigments (1). Dobriner and his associates have shown that coproporphyrin $I$ is formed as a by-product in the course of hematopoiesis (2a, b, c). Furthermore, they showed that the rate of production and excretion of coproporphyrin I depends upon the activity of orderly hematopoiesis $(3 a, b, c)$. Dobriner (4a, b) and Watson (5a, b, c, d, e) have established that the excreted coproporphyrin is chiefly, if not entirely, endogenous in origin. The greater proportion of the coproporphyrin is excreted by the liver into the intestinal tract and is found in the stool. There is a similarity between the pathways of excretion of coproporphyrin and the bile pigments.

Salkowski (7) and Garrod (9), in their early work on porphyrins, observed an increased urinary output of porphyrins in liver disease. Elevated urinary porphyrin excretion has been recorded in cases of passive congestion of the liver, cholangitis, catarrhal jaundice, luetic hepatitis, hemachromatosis, secondary carcinoma of the liver, acute and subacute liver atrophy, and cirrhosis $(4 \mathrm{a}, 6,10 \mathrm{a}$, b, 11a, b, 12, 13, 15, 16, 17, 18).

No suitable fecal coproporphyrin studies have been reported in cases of diseases of the liver. Brugsch (11a, b) and Vigliani (6) did not separate the fecal porphyrins into their components, hence their quantitative data for fecal porphyrin excretion comprise the total fecal porphyrins, and include deuteroporphyrin and protoporphyrin, which are partially exogenous in origin $(4 b, 5 e)$.
Brugsch (11a, b) suggested that there might be value in the determination of the relative excretion of urinary and fecal porphyrins in cases of liver disease.

It was reasoned that, since the coproporphyrin is excreted by the liver as well as by the kidney, the injured liver might be unable to excrete the total amount of coproporphyrin presented to it, and therefore this substance would accumulate in the blood stream and be excreted in the urine. Thus the urinary excretion would be increased at the expense of the fecal output. In cases of liver insufficiency, the ratio of urinary to fecal coproporphyrin should be elevated. In order to determine the amount of porphyrin cleared by the liver, only the coproporphyrin need be determined, since it alone is excreted in both urine and feces.

\section{METHODS}

The quantitative separation methods for coproporphyrin used in our studies are those of Dobriner (4a, b, 20). Quantitative measurements were done by means of a spectroscopic colorimeter (21).

All of the patients studied were on a regular diet. The entire urine and stool were collected for a period of seventy-two hours. In order to insure accurate collections of feces, capsules of brilliant blue were administered at the beginning and end of the seventy-two-hour test period, and the stool beginning at the first marker and ending just in front of the second marker was taken as a seventy-two-hour specimen. Actual determinations were done on aliquots of the stool and urine. The coproporphyrin output of the urine and stool was determined and the ratio of urinary to fecal coproporphyrin computed for a twenty-four-hour period. All cases studied were tested for the presence of bile pigments in the stool, and found to be positive.

\section{RESULTS}

Studies were done on a total of twenty-five cases. Of these, five (Cases 1 to 5, Table I) are in the normal group and the ratio of urinary to fecal coproporphyrin varied from 0.3 to 0.6. One 
of the normals (Case 5), a 27-year-old male in good general condition, was suffering from an inguinal furuncle with adenitis and had moderate fever during the course of the test. The total excretion in this case was elevated (585 gamma), although the ratio was within normal limits.

TABLE I

Coproporphyrin excretion in normals

\begin{tabular}{c|c|c|c|c|c|c}
\hline \hline Case & Age & Sex & $\begin{array}{c}\text { Urine } \\
\text { copropor- } \\
\text { phyrin }\end{array}$ & $\begin{array}{c}\text { Fecal } \\
\text { copropor- } \\
\text { phyrin }\end{array}$ & $\begin{array}{c}\text { Total } \\
\text { copropor- } \\
\text { phyrin }\end{array}$ & Ratio \\
\hline 1 & 25 & $\mathrm{~F}$ & 50 & 150 & 200 & 0.3 \\
2 & 26 & $\mathrm{M}$ & 130 & 205 & 335 & 0.6 \\
3 & 28 & $\mathrm{M}$ & 95 & 285 & 380 & 0.3 \\
4 & 29 & $\mathrm{M}$ & 150 & 245 & 395 & 0.6 \\
$* 5$ & 27 & $\mathrm{M}$ & 220 & 365 & 585 & 0.6 \\
\hline
\end{tabular}

* Fever.

Ten of the patients (Cases 10 to 19, Table III) fall in the category of cirrhosis. Two of these were of the juvenile portal type, one of the cardiac type, and the remainder of the classical portal variety. The diagnosis in five of these cases was verified by autopsy, biopsy, or peritoneoscopy. The urinary/fecal coproporphyrin ratio in these cases varied from 0.8 to 12.0 .

One patient with a ratio of 0.3 (Case 20, Table III) was convalescing from catarrhal jaundice, and manifested normal bromsulfalein and galactose tolerance tests.

Of the remaining nine cases, three (Cases 21 to 23, Table III) had secondary carcinoma of the liver, one of these being verified by biopsy. The urinary/fecal coproporphyrin ratios in these cases were $0.8,20.0$, and 22.0 .

A patient with a ratio of 4.3 (Case 24, Table III) was classified as essential xanthomatosis (22) ; and another (Case 25, Table III), with a ratio of 13.3 , was diagnosed as subacute liver atrophy.

Three patients (Cases 6, 7, 8, Table II) had doubtful liver insufficiency, although all had enlarged livers. The ratios in these patients varied from 0.45 to 0.7. The final case (Case 9, Table II), clinically designated as cirrhosis of the liver, had a normal bromsulfalein excretion and blood chemistry. This patient was operated upon. Liver tissue was not obtained for examination, although a portion of the greatly thickened capsule was examined. The diagnosis of the pathologist was "Chronic inflammation of the capsule of the liver which in some respects corresponds to the thickening seen in polyserositis." On reviewing this case, who had an ascites of three years' duration, it was found that she had had a previous operation for adhesive pericarditis. In spite of the clinical diagnosis of cirrhosis, we feel that this is not a case of parenchymal liver disease but one of polyserositis.

\section{DISCUSSION}

The coproporphyrin output in several normal males was determined by Dobriner, Strain, and Localio (2a). The total output varied between 306 and 376 micrograms per diem, of which 64 to 123 micrograms were excreted in the urine.

TABLE II

Coproporphyrin excretion in hepatomegaly without clinically disturbed liver function

\begin{tabular}{|c|c|c|c|c|c|c|c|c|c|c|c|c|c|c|c|}
\hline Case & Age & Sex & Diagnosis & $\begin{array}{l}\text { Red } \\
\text { blood } \\
\text { cells }\end{array}$ & $\begin{array}{l}\text { Hemo- } \\
\text { globin }\end{array}$ & $\begin{array}{c}\text { Ic- } \\
\text { terus } \\
\text { index }\end{array}$ & $\begin{array}{l}\text { Serum } \\
\text { bili- } \\
\text { rubin }\end{array}$ & $\begin{array}{l}\text { Cho- } \\
\text { les- } \\
\text { terol }\end{array}$ & $\begin{array}{l}\text { Cho- } \\
\text { les- } \\
\text { terol } \\
\text { esters }\end{array}$ & $\begin{array}{c}\text { Ratio } \\
\text { choles- } \\
\text { terol } \\
\text { esters/ } \\
\text { choles- } \\
\text { terol }\end{array}$ & $\begin{array}{c}\text { Brom- } \\
\text { sulf- } \\
\text { alein }\end{array}$ & $\begin{array}{c}\text { Urine } \\
\text { copro- } \\
\text { porphy- } \\
\text { rin }\end{array}$ & $\begin{array}{c}\text { Fecal } \\
\text { copro- } \\
\text { por- } \\
\text { phyrin }\end{array}$ & $\begin{array}{c}\text { Total } \\
\text { copro- } \\
\text { porphy- } \\
\text { rin }\end{array}$ & $\begin{array}{c}\text { Ratio } \\
\text { urinary/ } \\
\text { fecal } \\
\text { copro- } \\
\text { porphy- } \\
\text { rin }\end{array}$ \\
\hline 6 & 55 & $\mathrm{~F}$ & $\begin{array}{l}\text { Pyelonephritis } \\
\text { hepatomegaly }\end{array}$ & $\begin{array}{c}\text { millions } \\
3.94\end{array}$ & $\begin{array}{c}\text { grams } \\
12.3\end{array}$ & 5 & & & & per cent & $\begin{array}{c}\text { per cent } \\
16 \\
12\end{array}$ & 190 & 370 & 560 & 0.5 \\
\hline 7 & 67 & $\mathbf{M}$ & $\begin{array}{l}\text { Myxedema } \\
\text { hepatomegaly }\end{array}$ & 3.27 & 9.8 & 4 & $\begin{array}{l}\text { very } \\
\text { faint } \\
\text { trace }\end{array}$ & 235 & 95 & 41 & $\begin{array}{c}18 \\
\text { trace }\end{array}$ & 50 & 70 & 120 & 0.7 \\
\hline 8 & 18 & F & $\begin{array}{l}\text { Rheumatic heart dis- } \\
\text { ease, hepatomegaly }\end{array}$ & 4.02 & 13.5 & & & 170 & 70 & 41 & $\begin{array}{c}8 \\
\text { trace }\end{array}$ & 45 & 115 & 160 & 0.45 \\
\hline 9 & 40 & F & Polyserositis, ascites & 3.84 & 12.0 & & & 190 & 60 & 32 & $\begin{array}{l}8 \\
6\end{array}$ & 35 & 100 & 135 & 0.35 \\
\hline
\end{tabular}


TABLE III

Coproporphyrin excretion in cases with disturbed liver function

\begin{tabular}{|c|c|c|c|c|c|c|c|c|c|c|c|c|c|c|c|c|}
\hline Cace & Age & Sex & Diagnosis & $\begin{array}{l}\text { Red } \\
\text { blood } \\
\text { cells }\end{array}$ & $\begin{array}{l}\text { Hemo- } \\
\text { globin }\end{array}$ & $\begin{array}{c}\text { Io- } \\
\text { terus } \\
\text { index }\end{array}$ & $\begin{array}{c}\text { Serum } \\
\text { bilirubin }\end{array}$ & $\begin{array}{c}\text { Chol- } \\
\text { ester- } \\
\text { ol }\end{array}$ & $\begin{array}{l}\text { Chol- } \\
\text { esterol } \\
\text { esters }\end{array}$ & $\begin{array}{l}\text { Ratio } \\
\text { chol- } \\
\text { esterol } \\
\text { esters/ } \\
\text { chol- } \\
\text { esterol }\end{array}$ & $\begin{array}{c}\text { Brom- } \\
\text { sulfalein } \\
5 \text { mgm. dose } \\
30 \text { and } 60 \\
\text { minutes }\end{array}$ & $\begin{array}{c}\text { Galactose } \\
\text { tolerance, } \\
\text { Takata } \\
\text { Ars }\end{array}$ & $\begin{array}{c}\text { Urine } \\
\text { copro- } \\
\text { porphy- } \\
\text { rin }\end{array}$ & $\begin{array}{c}\text { Fecal } \\
\text { copro- } \\
\text { porphy- } \\
\text { nn }\end{array}$ & $\begin{array}{c}\text { Total } \\
\text { copro- } \\
\text { porphy- } \\
\text { rin }\end{array}$ & $\begin{array}{c}\text { Ratio } \\
\text { urinary I } \\
\text { fecal } \\
\text { copro- } \\
\text { porphy- } \\
\text { rin }\end{array}$ \\
\hline 10 & 19 & $\mathbf{M}$ & $\begin{array}{l}\text { Portal cirrhosis, juvenile } \\
\text { (biopsy) }\end{array}$ & $\begin{array}{c}\text { millions } \\
4.60\end{array}$ & $\begin{array}{c}\text { grams } \\
14.0\end{array}$ & 9.4 & $\begin{array}{c}\text { less than } \\
1.0\end{array}$ & 195 & 80 & $\begin{array}{c}\text { per cent } \\
41\end{array}$ & $\begin{array}{c}\text { per cent } \\
18 \\
12\end{array}$ & $\begin{array}{c}\text { negative/ } \\
\text { negative }\end{array}$ & 145 & 135 & 280 & 1.1 \\
\hline 11 & 18 & $\mathbf{F}$ & $\underset{\text { (peritoneoscopy) }}{\text { Portal cirrhosis, juvenile }}$ & 4.00 & 13.9 & 22.0 & 2.0 & 210 & 60 & 28 & $\begin{array}{l}40 \\
28\end{array}$ & 7.04 grams & 310 & 250 & 560 & 1.2 \\
\hline 12 & 46 & $\mathbf{F}$ & Cardiac cirrhosis & 4.42 & 12.6 & 6.8 & & 170 & trace & low & & & 100 & 115 & 215 & 0.9 \\
\hline 13 & 60 & $\mathbf{M}$ & Suggestive cirrhosis (biopey) & 4.56 & 13.5 & 10.0 & $\begin{array}{c}\text { leas then } \\
1.0\end{array}$ & 230 & 65 & 28 & $\begin{array}{l}20 \\
12\end{array}$ & negative & 75 & 85 & 170 & 0.8 \\
\hline 14 & $\mathbf{3 4}$ & $\mathbf{M}$ & Portal cirrhosis & & & 35.7 & 4.5 & 200 & & & $\begin{array}{l}40 \\
40\end{array}$ & & 150 & 165 & 315 & 0.9 \\
\hline 15 & 55 & $\mathbf{M}$ & Portal cirrhosis & 4.36 & 9.9 & 10.7 & & 130 & trace & low & $\begin{array}{l}38 \\
28\end{array}$ & & 110 & 85 & 195 & 1.3 \\
\hline 16 & 55 & $\mathbf{M}$ & Portal cirrhosis & 4.39 & 14.0 & 13.6 & $\begin{array}{c}\text { lese than } \\
1.0\end{array}$ & 375 & 180 & 48 & $\begin{array}{l}40 \\
28\end{array}$ & $\begin{array}{r}3.2 \text { grams/ } \\
\text { negative }\end{array}$ & 80 & 45 & 135 & 2.0 \\
\hline 17 & 48 & $\mathbf{F}$ & Portal cirrhosis & 2.84 & 10.2 & 33.8 & & 250 & 45 & 18 & $\begin{array}{l}40 \\
24\end{array}$ & negative & 125 & 55 & 180 & 2.3 \\
\hline 18 & 33 & $\mathbf{M}$ & Portal cirrhosis (autopay) & 4.62 & 14.0 & 125.0 & 26.0 & 180 & trace & $10 \pi$ & $\begin{array}{l}4+ \\
4+\end{array}$ & $\begin{array}{l}4.2 \text { grams/ } \\
\text { positive }\end{array}$ & 960 & 80 & 1040 & 12.0 \\
\hline 19 & 63 & $\mathbf{M}$ & Portal cirrhosis (autopay) & & & 34.1 & 3.8 & 335 & 70 & 21 & $\begin{array}{l}36 \\
32\end{array}$ & & 400 & 70 & 470 & 5.9 \\
\hline 20 & 21 & $\mathbf{F}$ & $\begin{array}{l}\text { Convalescent catarrhal jaun- } \\
\text { dice }\end{array}$ & 4.92 & 14.6 & 12.5 & & & & & $\begin{array}{l}6 \\
6\end{array}$ & negative & 50 & 185 & 235 & 0.3 \\
\hline 21 & 47 & $\mathbf{F}$ & $\begin{array}{l}\text { Secondary carcinoms of liver } \\
\text { (biopey) }\end{array}$ & 2.76 & 9.3 & 10.0 & $\begin{array}{c}\text { less than } \\
1.0\end{array}$ & 230 & 65 & 28 & $\begin{array}{l}20 \\
12\end{array}$ & negative & 75 & 95 & 170 & 0.8 \\
\hline 22 & 29 & $\mathbf{M}$ & Becondary carcinoma of liver & 3.46 & 11.9 & 40.9 & 7.3 & 355 & 115 & 32 & $\begin{array}{l}40 \\
28\end{array}$ & & 500 & 25 & 525 & 20.0 \\
\hline 23 & 51 & $\mathbf{M}$ & Secondary carcinoms of liver & 3.54 & 12.8 & 136.0 & 15.0 & 305 & 40 & 13 & 4t & & 220 & 10 & 230 & 22.0 \\
\hline 24 & 44 & $\mathbf{F}$ & Essential ranthomatosis & 3.20 & 11.0 & 83.0 & 12.0 & 360 & 125 & 35 & $\begin{array}{l}40 \\
36\end{array}$ & & 280 & 65 & 345 & 4.3 \\
\hline 25 & 22 & $\mathbf{M}$ & Subscute liver atrophy & 4.40 & 15.5 & 158.0 & 24.7 & 180 & 32 & 16 & $\begin{array}{l}40 \\
40\end{array}$ & & 200 & 15 & 215 & 13.3 \\
\hline
\end{tabular}

We have calculated the urinary/fecal coproporphyrin ratios in these cases and found them to vary from 0.2 to 0.6 . In our own group of cases, the urinary/fecal coproporphyrin ratio in normals varied from 0.3 to 0.6 .

In normal females the total excretion is slightly less but the ratio is unchanged. The lowered total excretion manifested by females is illustrated by Cases 1, 8, 12, and 20.

Dobriner and Rhoads (8), in their review of the porphyrins have stated that the total coproporphyrin I output is dependent on several factors, the principal one being the activity of the hematopoietic system.

In Tables II and III there are several cases exhibiting abnormally low total excretion. Six of these cases $(7,9,15,17,21,23)$ are seen to present secondary anemia. Two others $(13,16)$ have low excretory values which cannot be adequately explained.

Increased total coproporhyrin output in febrile states is illustrated by Cases 5 and 6 . In these cases, although the total excretion was increased, the ratios were within the range of normal. It is possible that the increased excretion in the presence of fever is due to the stimulating effects of elevated temperatures upon hematopoietic activity. With the exception of these two, all cases studied were afebrile during the course of the tests.

Dobriner (4a, b) and Vigliani and Libowitzky (23) have demonstrated the excretion of coproporphyrin III in a number of cases of liver disease such as melanocarcinoma, acute and subacute liver atrophy, and in some cases of cirrhosis. No attempt was made in the present study to ascertain whether coproporphyrin III was excreted in any 
of the cases, because sufficient material for melting point determination was not available. However, the high values obtained in four of the cases (Cases 11, 18, 22 and 24), in which there was no evidence of hyperactivity of the bone marrow and in which fever was not present, are possibly attributable to the excretion of coproporphyrin III in addition to the usual coproporphyrin I.

Because of these many divergent factors, the importance of determination of the urinary/fecal coproporphyrin ratios is emphasized in evaluating the status of the liver. It can readily be seen that a patient might exhibit a high urinary coproporphyrin excretion which would lead one to false conclusions in the absence of fecal coproporphyrin studies. However, the fecal coproporhyrin excretion might be at such a level that a normal ratio obtains, e.g., Case 5 with a urinary excretion of 220 , and Case 6 with a urinary coproporphyrin excretion of 190 . The converse may also be true, in that a case with a normal urinary coproporphyrin excretion with a low total output and low fecal coproporphyrin excretion may be included as normal, although the calculated ratio may be elevated, e.g., Cases 12, 13, 15, 16, 17, 21.

In the tests of liver function done concomitantly with the porphyrin excretion studies, it appears that the ratio of urinary/fecal coproporphyrin output more closely approximates the clinical evaluation of disturbance of liver function and the blood chemistry changes than do certain of these tests. The cholesterol ester/total cholesterol ratio was normal in five of the undoubted cases of liver insufficiency (Cases 10, 16, 21, 22, 24). In six of the fifteen abnormal cases studied, galactose tolerance tests were performed, and in three of these, all cases of liver insufficiency, the tests were within the range of normal. The Takata Ara test, done in three cases, was negative in two. Abnormal bromsulfalein retention was observed in all of the fifteen cases, although the retention in some of the cases does not appear to parallel the degree of liver insufficiency.

Since the procedure is dependent upon the integrity of the extra-hepatic biliary passages, it is obvious that it cannot be used in cases with obstruction of these passages.

\section{CONCLUSIONS}

(1) In the normal individuals studied, the ratio of urinary to fecal coproporphyrin varied from 0.3 to 0.6 .

(2) In cases of liver insufficiency this ratio was increased.

(3) The highest ratios were obtained in the cases exhibiting the most evident disturbance of liver function.

The authors wish to express their gratitude to Dr. Konrad Dobriner for the interest shown during the progress of this work.

\section{BIBLIOGRAPHY}

1. Fischer, H., and Orth, H., Die Chemie des Pyrrols, akademische Verlagsgesellschaft m.b.h., Leipzig, 1937, Vol. 2.

2a. Dobriner, K., Strain, W. H., and Localio, S. A., I. Quantitative measurement of coproporphyrin and total coproporphyrin I excretion in normals. Proc. Soc. Exper. Biol. and Med., 1937, 36, 752.

b. Dobriner, K., and others, II. Coproporphyrin I metabolism and hematopoietic activity. Ibid., 1937, 36, 755.

c. Dobriner, K., Excretion of porphyrin by dogs. Ibid., 1937, 36, 757.

d. Dobriner, K., and Rhoads, C. P., The excretion of coproporphyrin I following hemorrhage in dogs. J. Clin. Invest., 1938, 17, 105.

3a. Dobriner, K., Localio, S. A., and Strain, W. H., A study of the porphyrins excreted in congenital porphyrinuria. J. Biol. Chem., 1936, 114, xxvi.

b. Dobriner, K., and Rhoads, C. P., Metabolism of blood pigments in pernicious anemia. J. Clin. Invest., 1938, 17, 95.

c. Dobriner, K., Strain, W. H., Guild, H., and Localio, S. A., The excretion of porphyrins in congenital porphyria. J. Clin. Invest., 1938, 17, 761.

4a. Dobriner, $K$, Urinary porphyrins in disease. $J$. Biol. Chem., 1936, 113, 1.

b. Dobriner, K., Porphyrin excretion in the feces in normal and in pathological conditions. Ibid., 1937, $120,115$.

5a. Watson, C. J., Concerning the naturally occurring porphyrins. I. Isolation of coproporphyrin I from the urine in a case of cinchopen cirrhosis. J. Clin. Invest., 1935, 14, 106.

b. Idem, II. The isolation of a hitherto undescribed porphyrin occurring with an increased amount of coproporphyrin $I$ in the feces in a case of familial hemolytic jaundice. Ibid., 1935, 14, 110.

c. Idem, III. Isolation of coproporphyrin I from the feces of untreated cases of pernicious anemia. Ibid., 1935, 14, 116. 
d. Idem, IV. The urinary porphyrin in lead poisoning as contrasted with that excreted normally and in other diseases. Ibid., 1936, 15, 327.

e. Idem, V. Porphyrins of the feces. Ibid., 1937, 16, 383.

6. Vigliani, E. C., Ricerche sul ricambio delle porfirine nelle affezioni epatiche e sulla eliminazione del copro- e della protoporfirina iniettate endovena nell'uomo. Arch. per le sc. Med., 1938, 65, 391.

7. Salkowski, E., Ueber Vorkommen und Nachweis des Haematoporphyrins im Harn. Ztschr. f. physiol. Chem., Strassb. 1891, 15, 286.

8. Dobriner, K., and Rhoads, C. P., The porphyrins in health and disease. Physiol. Rev., 1940. (In Press.)

9. Garrod, A. E., Inborn Errors of Metabolism. H. Frowde, London, 1923, 2 ed.

10a. Thiel, W., and Kaemmerer, H., Quantitative Porphyrinmessungen bei verschiedenen Krankheiten, insbesondere bei Leberfaellen. Verhandl. d. deutsch. Gesellsch. f. inn. Med., Kong. 1933, 45, 81.

b. Thiel, W., Qualitative und quantitative Bestimmung des Urinporphyrins. Klin. Wchnschr., 1934, 13, 700.

11a. Brugsch, J. T., Die sekundaeren Stoerungen des Porphyrinstoff wechsels. Ergeb. d. inn. med. und Kinderh., 1936, 51, 86.

b. Untersuchungen des quantitativen Porphyrinstoffwechsels beim gesunden und kranken Menschen; der Porphyrinstoffwechsel bei Lebererkrankungen. Ztschr. f. d. ges. exper. Med., 1935, 95, 493.

12. Kaunitz, H., Ueber Porphyrinurie nach Haemoglobinbelastung. Ztschr. f. klin. Med., 1938, 133, 552.

13. Tropp, C., and Penew, L., Quantitative klinische Harnporphyrinuntersuchungen; Lebercirrhosen, Hepatopathien (ausser Cirrhosen), Tuberkulose und andere Krankheiten. (Zugleich ein Beitrag zur Verbesser- ung und Vereinfachung der Bestimmungsmethode). Deutsches Arch. f. klin. Med., 1937, 180, 411.

14. Lageder, K., Klinische Porphyrinuntersuchungen mit einer quantitativen spektroskopischen Methode. Arch. f. Verdaungskr., 1934, 56, 237.

15. Guenther, H., Die bedeutung der hamatoporphyrine in physiologie und pathologie. Ergebn. d. Allge. Path. u. path. Anat., 1922, 20, Part 1, 608.

16. Franke, K., Klinische und lebendmikroskopische Untersuchungen der gestoerten Leberfunktion; Untersuchungen ueber beginnende Leberschaedigungen unter besonderer Beruecksichtgung der Porphyrinausscheidung im Urin. Ztschr. f. klin. Med., 1936, $130,222$.

17. Lorente, L., and Scholderer, H., Experimentelle und klinische Porphyrinuntersuchungen. Arch. f. Verdauungskr., 1936, 59, 188.

18a. Eppinger, H., Die hepato-lienalen Erkrankhungen. J. Springer, Berlin, 1937.

b. Eppinger, H., Die Leberkrankheiten. J. Springer, Berlin, 1937.

19. Vannotti, A., Porphyrine und Porphyrinkrankheiten. J. Springer, Berlin, 1937.

20. Dobriner, K., and Rhoads, C. P., Quantitative determination of urinary coproporphyrin. New England J. Med., 1938, 219, 1027.

21. Mattice, M. R., Gannon, C. F., and Green, C. H., Spectrocolorimetry; adaptation of a colorimeter for evaluating absorption spectra. J. Lab. and Clin. Med., 1940, 25, 629.

22. Thannhauser, S. J., and Magendantz, H., Different clinical groups of xanthomatous diseases; clinical physiological study of 22 cases. Ann. Int. Med., 1938, 11, 1662.

23. Vigliani, E. C., and Libowitzky, H., Ueber Porphyrine im Harn und im Kot. Klin. Wchnschr., 1937, 16, 1243. 